\title{
Thede Kahl, Peter Mario Kreuter \& Christina Vogel (eds), Vergessen, verdrängt, verschwunden. Aufgegebene Kulturen, Beziehungen und Orientierungen in der Balkanromania, Frank \& Timme, Berlin, 2018, 360 p.
}

\author{
Dinu Moscal ${ }^{\oplus *}$ \\ Institutul de Filologie Română „A. Philippide”, Str. Th. Codrescu 2, 700481 Iași, România
}

Acest volum, al 35-lea din seria „Forum: Rumänien”, reuneste lucrările conferinței de romanistică balcanică cu același titlu (a cărui traducere în română ar fi: „Uitare, periclitare, dispariție”. Culturi, relații și tendințe abandonate in Romania balcanică), care a avut loc la Münster între 29-31 mai 2014 (p. 11). Romanitatea balcanică a fost supusă unei presiuni continue a altor culturi, iar acest lucru se reflectă întrun statut identitar precar al aproape tuturor comunităților romanice, lucru valabil și în cazul comunității românești din afara granițelor României. Contribuțiile din acest volum încearcă să ofere o imagine a culturilor și limbilor romanice balcanice care prezintă riscul dispariției sau al asimilării de către alte culturi, dar și încercările de revigorare a identității lor în cadrul dinamicii influențelor culturale și lingvistice din acest spațiu. Studiile au fost organizate în trei secțiuni, în funcție de nivelul la care este abordată această problematică: cultură, literatură, limbă.

Prima secțiune, Kulturwissenschaft (p. 15-173), este deschisă prin contribuția cunoscutului românist, elev al lui Eugenio Coseriu, Rudolf Windisch, Aufgegebene Kulturen, Beziehungen und Orientierungen in der Balkanromania (p. 15-34), în care autorul abordează problematica autodeterminării băieșilor („,tiganii aurari” descriși de Dimitrie Cantemir în Descriptio Moldavia, cunoscuți mai mult sub numele de „rudari”) și a caravlahilor („vlahii nordici”, în raport cu cei din Grecia) din Bosnia și Herțegovina. Autorul stabilește din start o semnificație diferită pentru conceptul de „identitate etnică”, pe care o definește prin prisma autodeterminării, adică de ce etnie se consideră a fi indivizii acestor comunități prin raportare la originea lor și la apartenența lor la un grup prin limbă, cultură și structură socială. În acest scop sînt utilizate cinci tipuri de autodeterminare etnică, bazate pe limba declarată a interlocutorilor. Autodeterminarea lingvistică nu corespunde însă întotdeauna cu cea etnică. Unele grupuri de băieși se consideră de etnie romă (probabil prin etnonimul „țigani”, aşa cum se declară în general cei care locuiesc în comunități tradiționale, neinfluențaţi de aşa-zisa „corectitudine politică”), însă vorbesc româneșće sau țigăneşće; în schimb, există caravlahi care se consideră băieși (p. 23). Tema este dezvoltată prin problema conștiinței etnice din Republica Moldova, unde identitatea etnică de „moldovean”, adică apartenența la unul dintre cele trei principate românești (românii din Republica Moldova, inclusiv din regiunea Moldova din estul României), este asumată ca identitate etnică diferită de cea de „român”, iar, prin analogie, limba română este numită limbă „moldovenească”. Folosindu-se de date statistice și luînd în considerare factorii ce pot influența autoidentificarea lingvistică, dintre care unul foarte important este propaganda politică, autorul face o scurtă analiză a criteriului lingvistic ca factor al identității etnice în Republica Moldova.

În următorul articol, Erforschung und Dokumentation schwindender Sprachen und Kulturen. Romanisches Feldmaterial aus Südosteuropa in den Projekten VLACH und LAZAR (p. 35-58), Thede Kahl, un foarte bun cunoscător al problematicii minorităţilor românești (și numai) din Balcani, în special prin anchetă directă, face întîi o scurtă prezentare a etapelor care conduc spre dispariția unei limbi (diminuarea comunității ce vorbește o limbă, urmată de stigmatizarea socială a respectivei limbi şi apoi de reducerea vocabularului acesteia), urmată de prezentarea situației lingvistice actuale a limbilor și dialectelor romanice din această zonă. Sînt prezentate apoi inițiativele de pînă acum privind documentarea și arhivarea limbilor / dialectelor amenințate cu dispariția. Cele

*Adresă de corespondență: dinu.moscal@gmail.com. 
două proiecte anunțate în titlu sînt iniţiative mai noi, iar în spațiul de referință intră și regiunea balcanică, motiv pentru care acestea au o mare importanță în conservarea datelor privind Romania Balcanică. Proiectul LAZAR (Langzeitarhivierung regionalwissenschaftlicher Forschungsdaten; lazar.gbv.de), prin tematica sa, prelucrarea şi arhivarea datelor etnologice și lingvistice obținute de cercetătorii din diverse regiuni, adună și date despre limbile/ dialectele regionale amenințate cu dispariția. VLACH (Vanishing languages and cultural heritage; oeaw.ac.at/vlach) este un proiect care utilizează și o parte din datele stocate prin primul proiect, iar scopul este analizarea fenomenului dispariției limbilor de către o comisie cu un înalt grad de specializare. Autorul articolului, cu un rol important în ambele proiecte, prezintă rezultatele şi paşii ce urmează în cadrul proiectului VLACH în ceea ce privește romanitatea balcanică.

Astfel de inițiative pentru conservarea limbilor și culturilor amenințate cu dispariția presupun un efort deosebit și nu pot fi decât admirate. Ce se va întîmpla însă cu acest tezaur? Un alt teazur, incontestabil mai valoros, limba și cultura latină, pare să nu se bucure de un tratament favorabil într-o universitate de tradiţie din același spațiu. Conducerea Universităţii din Salzburg intenționează retragerea singurului post de latină din această prestigioasă instituție la împlinirea a 400 de ani de la înființare (1622).

Edda Binder-Iijima reia o temă mult discutată și contestată, constituirea unei uniuni balcanice: Present in absentia: Die Idee der Balkanunion (p. 5973). În contextul unei posibile coeziuni politicoadministrative a zonei balcanice prin aderarea tuturor statelor din acest spațiu la Uniunea Europeană, autoarea discută ideile pe această temă care au circulat de la sfîrșitul secolului al XVIII-lea pînă astăzi. Momentul ad quem îl constituie scrierile politice ale lui Rigas Velestinlis, care atrage atenția că lipsa de unitate în spațiul balcanic nu este cauzată doar de diversitatea etnică și religioasă, ci și, îndeosebi, de instabilitatea autorității, de lipsa egalității în drepturi, de violența și de lipsa unei legislații din timpul dominației otomane, care au lăsat o amprentă cu urmări profunde în conștiința comună. Scepticismul lui Rigas, împărțirea autorității asupra acestui spaţiu între puterile din jur, așa cum își imagina prințul polon Adam Czartoryski, impulsul național de la 1848, completat de ideea unei unități transnaționale în contraponderea marilor puteri din jur, ideile socialiste de după primul război mondial, planurile comuniste de după al doilea război mondial—toate acestea sînt prezentate cronologic pentru a avea o imagine sinoptică a spațiului balcanic în ultimele două secole și o înțelegere a problematicii acestui spațiu în vederea unei uniuni balcanice prin Uniunea Europeană. Totuși, nu putem să nu remarcăm că acest „spațiu de manevră” dintre cele trei mari puteri (cea otomană, cea rusă și cea germanică) nu a căpătat încă o independență totală față de două dintre reprezentările actuale ale celor trei puteri pentru a putea intra fără anumite sacrificii sub autoritatea celui de-al treilea. Independența totală a acestei zone și constituirea unei uniuni balcanice propriu-zise rămîne $\mathrm{cu}$ siguranță utopică.

Urmează două articole semnate de Horst Fassel (volumul este dedicat memoriei acestuia). În primul dintre ele (p. 75-125) este pusă în evidență contribuția culturală a editurii „Regele Carol” din București în perioada în care provinciile istorice Țara Românească și Transilvania au fost sub ocupaţie germană (1917-1918). Cititorul poate găsi aici istoricul instituirii editurii, contextul editorial al vremii, domeniile lucrărilor publicate și traducerile în germană din literatura populară și cea cultă, cu un repertoriu al acestora în finalul articolului. În anexă sint redate traducerile a patru poezii ale lui Eminescu. Al doilea articol este o încercare de reabilitare a operei dramatice a lui vasile Alecsandri: Vasile Alecsandri - ein Vergessener? Kann man Kleintheater von anno 1843-1870 wieder auf die Bübne bringen? (p. 127149). Autorul subliniază importanța comediilor lui Alecsandri, prin care se configurează o imagine a unei epoci Moldovei și a capitalei acesteia, marcate de o anumită mentalitate, de încercările de emancipare a anumitor clase sociale, de dialogul intercultural marcat de rafinatul cunoscător de limbă prin inserții lingvistice străine (grecești, franțuzești, germane, turcești, rusești, armene și țigănești). Autorul articolului vede în creația teatrală a lui Alecsandri un model de conviețuire paşnică și toleranță într-o societate multietnică (ceeea ce nu exclude mijloacele specifice ale comediei, printre care și caricatura), model care ar trebui să inspire societatea actuală. Desigur, există un repertoriu constant al operei lui Alecsandri pe scena românească, însă o mare parte din opera sa dramatică este pe nedrept uitată, lucru pe care Horst Fassel îl accentueză în acest articol, dar nu fără a semnala că acelaşi lucru se poate afirma despre întreaga operă 
a lui Alecsandri, a cărei importanță în evoluţia literaturii române este în general ignorată sau chiar subestimată.

Jürgen Kristophson abordează dificila temă a romanității actuale în Dalmația: Im slawischen Meer verschwindende Dalmatiner und auftauchende Rumänen (p. 151-162). Limba romanică cu care este asociată această zonă este dalmata, documentată de Bartoli prin dialectul vegliot. O reevaluare a dalmatei pe baza datelor actuale se dovedește o încercare extrem de dificilă, deoarece eventualele reminiscențe ale acestei limbi au suportat transformări al căror istoric nu este documentat, la care se adaugă posibilitatea interpretării greșite a unor elemente romanice non-dalmate. Situaţia este de cele mai multe ori similară și în cazul acestora din urmă. Astfel, în afară de cele două dialecte dalmate, cel ragusan şi cel vegliot, se adaugă în ecuația romanităţii din acest spațiu dialectul venet și cel istroromân şi chiar elemente românești, fie ca împrumuturi în sîrbocroată, fie ca reminiscențe toponimice. Autorul ajunge la cîteva observații privind evoluțiile fonetice (nealterarea consoanelor $p, t, k, s$ în poziție intervocalică, nepalatalizarea guturalelor urmate de $e$ sau $u$ ). În contextul sensurilor cuvîntului vlah în sîrbocroată este adusă în discuție și semnificația etnonimului caravlah și a variantei grecești evoluate la morlac, dar cu limitarea la sensul principal a determinantului (tc. cara 'negru'), fără a se lua în considerare sensul de 'nord' preluat din cultura asiatică (cf. și denumirile tc. Kara Deniz „Marea Neagră” și Ak Deniz „Marea Albă” pentru Marea Mediterană, nume existent și în limba română în perioada premodernă, culori care desemnează punctele cardinale nord și vest în raport cu capitala Imperiului Otoman).

În ultimul articol din prima secțiune, Inrudirea formelor urbane: Cvartaluri realist-socialiste in Braşov. Hof-uri vieneze. Remembering Lessons of Communal Housing: The Vienese Hof and the Stalinist Kvartal (p. 163-173), Miruna Stroe face o analiză comparativă a două stiluri arhitecturale de origini diferite, dar bazate pe principii similare, în scopul creării unui spațiu de locuit care asigură facilitățile necesare claselor mai puțin privilegiate financiar. Înnoirea Orașului Stalin, adică al Brașovului sub acest nou nume, prin impunerea unei noi arhitecturi, cea a cvartalurilor, începînd cu anul 1952 și în prima parte a deceniului următor, s-a dovedit o inițiativă fastă, chiar dacă lipsită de monumentalitate. Autoarea precizează facilitățile oferite de acest tip arhitectural înrudit cu Hof-urile vieneze, prezente în același oraș, dar și contrastul cu arhitectura socialistă ce i-a urmat, aceasta din urmă marcând încă toate orașele mari din România. Planurile arhitecturale și fotografiile construcțiilor de la finalul articolului îi pot edifica pe cititori într-un mod mai direct.

A doua secțiune (p. 175-287) cuprinde șase articole dedicate unor autori sau anumitor teme particulare din spațiul literaturii balcanice, care, deși au o certă valoare și specificitate, se află astăzi într-un plan secundar sau chiar ignorate.

În articolul Vergessen und vergessen werden im Leben und Werk von Matila C. Ghyka (p. 177-196), primul din secțiunea Literaturwissenschaft, Ilina Gregori redă prezentului figura unei personalități pe nedrept căzută în uitare, Matila C. Ghyka, nepotul ultimului domn al Moldovei, Grigore Alexandru Ghica. Matila C. Ghyka, o personalitate complexăstudii încheiate la „École navale” din Brest, la „École Supérieure d'Électricité" din Paris și doctor în drept la „Universitaté Libre” din Bruxelles, de profesie ofițer de marină, diplomat și profesor de estetică, semantică și filozofie la Universitatea din California de Sud-se remarcă și ca memorialist, teoretician al esteticii și romancier. Deoarece este cunoscut în special ca estetician prin Le nombre d'or. Rites et rythmes pythagoriciens dans le développement de la civilisation occidentale (1931), prefațată de o scrisoare a lui Paul Valéry referitoare la o lucrare anterioară din același domeniu (Esthétique des proportions dans la nature et dans les arts, 1927), autoarea dedică acestei teme cîteva pagini la începutul studiului său, unde cititorul are acces la o scurtă sinteză a viziunii sale asupra esteticii proporțiilor. Se adugă o scurtă prezentare a carierei sale diplomatice la Viena, necesară pentru o apreciere adecvată a romanului Ploaie de stele (tradus în limba română în 2007), prezentarea acestuia constituind ultima parte a încercării de restaurare a memoriei unui autor pe nedrept uitat. Sînt evidențiate mijloacele prin care autorul romanului construiește o imagine psiho-socială a Europei în contextul politico-istoric de după primul război mondial, pusă în contrast cu „,vechea” Europă, cea de dinainte de război. Stelele vechii aristocraţii cad, iar în locul acestora răsare o societate disparată, în căutarea unei noi identități, surprinsă în toate compartimentele vieții, de la îmbrăcăminte, comportament, tradiție 
pînă la componenta spirituală și la gustul artistic. Alte aspecte ale personalităţii prezentate în acest articol pot fi descoperite în volumul monografic, Păstrat in uitare? Matila Ghyka. Numărul și Verbul (2018), anunţat, am putea spune, prin studiile din ultimii ani ale Ilinei Gregori.

În Sprachmischung als kulturelle Überlenensstrategie: romanische Minderheitensprachen und Literatur in Istrien (p. 197-214), Robert Lukenda supune atenției un fenomen relativ nou în literatură: multilingvismul. În contextul multicultural, multietnic şi multilingvistic al Istriei, fenomenul multilingvismului în literatură nu poate fi privit ca un mijloc de exprimare a unor valori stilistice, estetice sau pentru a reda un anumit colorit local, ci ca o reflectare aproape „naturală” a acestei realităţi de care, în afară de celelalte aspecte deja menționate, sînt legate și conflictele identitare, culturale și politice. Deși istrovenețiana are statut de lingua franca în peninsulă, întreaga zonă se identifică prin bilingvism și trilingvism. Exploatarea acestui aspect în literatură, favorizind dialogul multietnic, multicultural și multilingvistic, și, în acelaşi timp, fiind în opoziție cu tendințele de uniformizare promovate în special prin mijloace politice, indică cealaltă cale a identității, prin refuzul globalizării şi prin păstrarea dialogului între minorităţi și a respectului faţă de valorile tradiționale ale fiecăreia dintre acestea.

Anita Andreea Széll (p. 215-236) anunță o abordare dintr-o perspectivă diferită a volumului $S z a ́ z$ fabula ( $O$ sută de fabule), al unui mare cărturar al Cetății Clujului din sec. al XVI-lea, Heltai Gáspár, scriitor de limbă maghiară, dar sas de origine (Caspar Helth). Autoarea acordă întîi atenție acestei dualități germano-maghiare a autorului, apoi, bazîndu-se în special pe analizele a trei autori, încearcă o sintetizare a percepției tradiționale a fabulelor sale și a locului pe care acestea îl ocupă în cadrul literaturii maghiare. Autoarea anunță o nouă metodă de interpretare a celor $O$ sută de fabule, cu rezultate diferite de cele cunoscute acestei specii literare, și anume: identificarea trăsăturilor etnografice specifice satelor ,ascunse în munții și dealurile Transilvaniei” (p. 226) din epoca respectivă. Însă întreaga pregătire a acestei noi perspective este continuată doar prin cîteva posibile interpretări ale unei singure fabule, Lupul, vînătorul și ciobanul, dar nu în direcția anunțată, ci încercînd să argumenteze posibilitatea analizei fabulei prin prisma naratologiei (vocea narativă, naratarul), prin precizarea rolurilor din fabulă, prin identificarea tipurilor de comunicare și a simbolisticii realităților care apar în fabulă. Totuși, aceste „noi” metode de analiză se limitează la un nivel general sau la simple propuneri, expuse în cîteva rînduri, fără o analiză propriu-zisă, motiv pentru care nici nu apar mențiuni în această privință în secțiunea concluziilor, aceasta referindu-se strict la prima parte a articolului.

Articolul La narrativa francófona del siglo XX: un escenario para la memoria del exilio (p. 237-250), al Laurei Eugenia Tudoras este, de fapt, o analiză a romanului lui Vintilă Horia, Dieu est né en exil. Journal d'Ovide à Tomes, autoarea evidențiind liniile valorice ale romanului: un jurnal imaginar al eului interior al artistului, care, prin exil, descoperă noi dimensiuni ale existenței. Exilul îl aşază într-o nouă realitate, iar vechea realitate se transformă prin percepția de la distanță, fixată în planul memoriei. În ambele planuri funcționează o percepție conștientizată, supusă unor transformări profunde, pe care autoarea le punctează printr-o lectură analitică a romanului.

Urmează (p. 251-275) o analiză foarte echilibrată a Poveștilor Peleșului, scrise de Carmen Sylva, adică Regina Elisabeta a României. Titlul articolului oferă indicii clare despre perspectiva analizei: Die „rumänischen Märchen” der ,deutschen Königin” Rumäniens: Elisabeth zu Wied - Carmen Sylva (18431916). Aspekte rumänischer Volkskultur, deutschrumänische Kulturvermittlung und politische Symbolik in Carmen Sylvas Märchen. Autoarea, Silvia Irina Zimmerman, ne oferă întîi cîteva detalii despre Carmen Sylva, apoi face un scurt istoric critic al receptării poveștilor lui Carmen Sylva în Germania, în care accentuează informația pusă între ghilimele în prima parte a titlului, mai exact, caracterul cult al poveștilor, chiar dacă elementele românești apar în mod frecvent, chiar programatic, la care se adugă formulele tipice basmelor românești. Urmează o analiză atentă a simbiozei motivelor românești cu cele germane și a impactului cultural-politic al operei literare a primei regine a României.

În ultimul articol al acestei secțiuni, Renate Windisch-Middendorf prezintă drumul sinuos al existenței poetului evreu Manfred Winkler (19222014): Vergessen - verdrängt - verschwunden? Vom Kakanier aus der Bukowina zum zweisprachigen Dichter in Israel: Manfred Winkler (p. 277-287). Educația în orașul natal, Cernăuți, multietnic și multicultural, războiul cu urmările sale asupra familiei sale și 
asupra lui însuși, șederea în România, emigrarea în Israel, specificitatea creației sale poetice, toate acestea îi apar cititorului nu doar prin informația istorică exactă și analiza critică și comparativă a poeziei sale, ci şi prin citate din jurnalul poetului și prin poeziile inserate în text (doar începutul, în cazul uneia), perfect îmbinate cu planul de discurs al autoarei.

Partea a treia, Sprachwissenschaft (p. 289-356), cuprinde trei articole, două privitoare la limba română, unul, cel final, la limba (neo)greacă.

Primul articol tratează una dintre categoriile gramaticale moștenite din latină, dar nespecifice întregii romanități: genul neutru. La fel ca şi supinul, neutrul românesc nu are încă o imagine clară în comunitatea științifică, atît în ceea ce privește statutul său, cît şi în ceea ce privește istoricul său, deși există suficiente argumente în favoarea continuității sale în spațiul romanic și al supraviețuirii sale în limba română. Aceste argumente, dar și problema receptării lor, fac obiectul studiului Luminiței Fassel, Das Schicksal des lateinischen Neutrums in der Romania oder "neutrul latin, soartă și destin” (p. 291-302). Autoarea prezintă argumentele de ordin lingvistic, insistînd asupra istoricului neutrului în întreaga Romanie, cu reminiscențe existente și astăzi. Un aspect și mai important este însă lipsa receptării argumentaţiei clare în privința conservării neutrului în limba română (şi în faze istorice mai vechi în italiană, franceză, provensală și spaniolă, cu elemente formale păstrate pînă astăzi) a unor lingviști cu autoritate în domeniu, începînd cu W. Meyer-Lübke. Mai mult decît atît, acesta a fost receptat greșit de comunitatea științifică, în care $s$-a transmis contrariul demonstrației sale. Autoarea atrage atenția asupra acestui fenomen al receptării artificiale și chiar al generalizării acesteia, prin acceptarea unui punct de vedere fără cercetarea personală a surselor primare.

Urmează un studiu extins, Das Schicksal der Turzismen und Gräzismen bei der Gestaltung des modernen Rumänischen (p. 303-343). Autorul, Alexandru Cizek, oferă întîi o excelentă prezentare sinoptică a cadrului istoric și cultural (p. 303-310), cu detalii suficiente și unui cititor mai puțin avizat în privința complexității politice, istorice și lingvistice a provinciilor românești începînd cu perioada medievală și continuînd, în zone destul de extinse, pînă astăzi. Aspectele istorice și culturale sînt întotdeauna completate cu efectele lor în plan lingvistic, autorul urmărind schimbările semantice ale lexemelor împrumutate și reflexele lor la nivel istoric, dialectal (inclusiv specificarea zonelor de influență greacă și cele de influență turcă), socio-cultural (printre care și inevitabilul "conflict” cu împrumuturile din franceză) și stilistic. O observație accentuată în text este diferenţierea între împrumuturile care suferă schimbări semantice și împrumuturile care îşi conservă semnificația cu care au intrat în limba română: primele aparțin în general registrului familiar, cele cu sensul primar au rămas în registrul general, chiar dacă multe au devenit arhaisme. Urmează analiza împrumuturilor, prezentate pe nivel de limbă (arhaisme, cuvinte care au suferit schimbări semantice și cuvinte care nu au suferit schimbări semantice), întîi grecismele, apoi turcismele, fiecare organizate pe domenii (terminologii), folosind sursele lexicografice generale și speciale, dintre care se remarcă în primul rînd contribuțiile lui Lazăr Șăineanu.

Ultimul articol abordează o problemă situată în afara spațiului de referință al volumului, Antikisie-

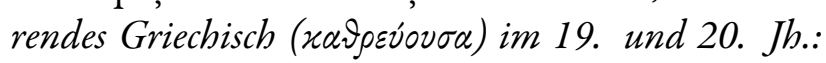
Alte Sprachformen als Ingredienz des Nazionalismus (p. 345-356), astfel că autorul, Johannes Kramer, argumentează întîi relevanța articolului în cadrul acestui volum, prin ilustrarea condiţiilor și intențiilor politice și istorice în cazul încercării de a revigora o limbă și prin paralela cu afirmarea latinității limbii române și a încercărilor de latinizare o dată cu afirmarea națională, inclusiv regula ortografică din $1993 \mathrm{cu}$ privire la caracterul $\hat{a}$ pentru $\hat{\imath}$ intervocalic fiind argumentată prin trimiterea la limba latină. Sînt punctate întîi etapele istorice ale limbii grecești, începînd $\mathrm{cu}$ perioada preromană și continuînd $\mathrm{cu}$ cea romană, cu greaca bizantină, cu tendințele de reconstrucție a vechii limbi grecești, cu dificultățile din perioada Imperiului Latin și din perioada de după căderea Constantinopolului, cu epoca fanariotă, marcată de acțiuni energice pentru revitalizarea limbii înaintașilor, tendințe accentuate o dată cu eliberarea națională. Eforturile de „anticizare” a limbii în această ultimă etapă sînt analizate mai detaliat, în paralel cu instabilitatea politică și cu realitatea socială, autorul evidențiind cauzele care au condus

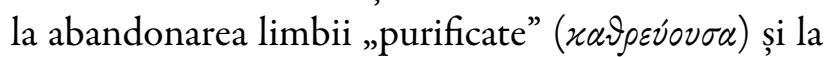
treptele oficializării variantei $\delta \eta \mu o \tau \imath x \eta ́$. În finalul articolului autorul atrage atenția asupra faptului că o cultură nu poate fi pur și simplu abandonată în cazul în care aceasta este parte componentă a istoriei 
unei națiuni, aşa cum se întîmplă cu greaca veche, care a fost revigorată în Grecia o dată cu renașterea națională de la începutul secolului al XIX-lea. Autorul consideră că și limba română are un parcurs asemănător în ultimele două secole, prin afirmarea latinității, dar și prin abandonarea scrierii chirilice și deschiderea către întreaga romanitate.
În concluzie, volumul oferă o imagine din mai multe perspective asupra românității balcanice, imagine ce reflectă complexitatea istoricului politic, cultural și lingvistic, dar şi o continuitate a unei identități romanice într-un spațiu supus constant unor influențe și presiuni alogene. 